\title{
THE RELATION BETWEEN THE CRITICAL PERIOD FOR ACCENT ACQUISITION, NATIONAL IDENTITY (JEWISH/ISRAELI) ASSIMILATION, AND LANGUAGE SKILLS
}

\author{
Wael Shakkour, Salim Abu-Rabia, Yaniv Lev \\ Faculty of Education University of Haifa, Israel \\ Nazareth Institute (NI) for Bilingualism \\ waelshakk@hotmail.com
}

\begin{abstract}
This study examines the correlation between Jewish/Israeli identity, pronunciation levels, the critical learning age period, and accent. The sample pool consisted of fifty Russian immigrant students and ten native-born Israeli citizens who were administered a 3-part questionnaire composed of questions relating to linguistic ability, heaviness of accent, and sense of Israeli identity. Accent was assessed by oral tests in which the participants were asked to perform various verbal taskssuch as repeating pseudo-words, pronouncing words with phonetic omissions, vocabulary tests, and listeningcomprehension tests. Israeli identity was evaluated by a 23 -item identity questionnaire. The findings indicate that a heavy accent is linked to a weaker sense of Israeli identity, the critical-age period also playing a central function in influencing vocabulary retention and learning skills. These parameters corresponded to the age of arrival in the country. No correlation was obtained between heaviness of accent and linguistic learning skills.
\end{abstract}

Keywords: native accent; Jewish/Israeli identity; pronunciation; critical learning age, immigrant

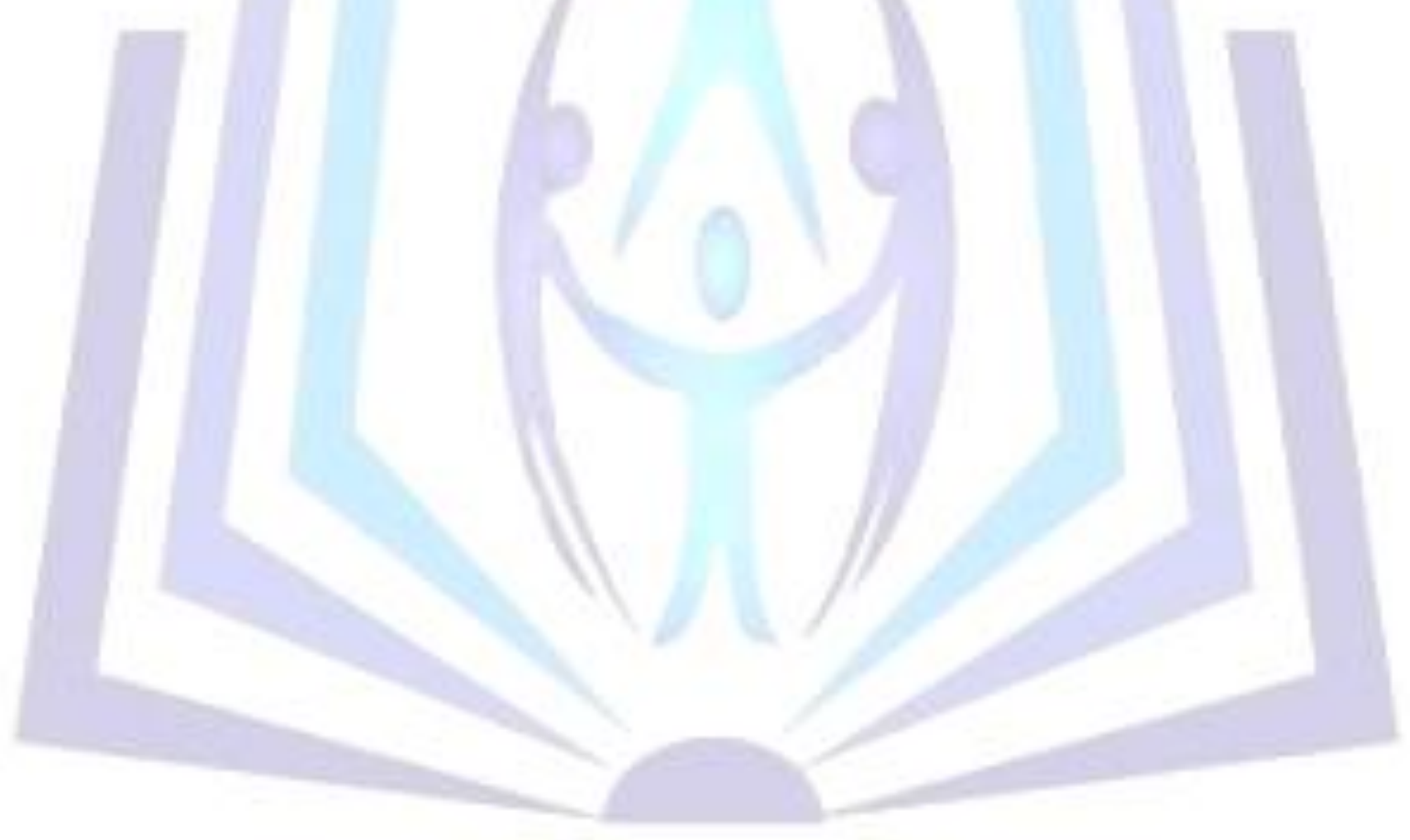

\section{Council for Innovative Research}

Journal: Journal of Advances in Linguistics

Vol .5 No 2

editor@cirjal.com

www.cirjal.com, www.cirworld.com

\section{IN I KUUUL' I IUIV}


Language is one of the key factors affecting the way immigrants integrate into their new society and culture, as numerous socio-psychological studies have suggested. The shift from their mother tongue to the local language plays a central role in immigrants' acculturation process (Alba, 1999). Likewise, active bilingualism constitutes a crucial factor in social mobility (Remennick, 2004).

Under Israel's Law of Return all Jews, whatever their country of origin, possess the right to Israeli citizenship. Thus, Israel serves as a prime example of the way in which diverse groups can be integrated within a majority society/culture. By studying the various waves of immigration to Israel we may identify the factors that significantly affected the success or failure of the immigrants' integration. When Soviet Jews emigrated to Israel in the 1970s, for example, their social and cultural ties were irreparably with their homeland cut because of the hostility between the two countries (Olshtain \& Kotik, 2000). These immigrants, who assimilated into Israeli society largely by mastering the target language, stand in stark contrast to the immigrants from the Former Soviet Union (FSU) in the 1990s, who retained stronger bonds with their mother tongue and cultural heritage, because they were able to preserve close links with friends and family in their native land (Olshtain \& Kotik, 2000).

Israel also constitutes a unique case due to the fact that reviving the Hebrew language formed an integral part of the establishment of the modern sovereign Jewish national state. In its early years speaking of any other language was proscribed and the majority of immigrants relinquished the use of their mother tongue. Over the past two decades, however, a more pluralistic attitude towards multilingualism has developed within Israeli society, engendering more liberal and positive attitudes towards the preservation of immigrant cultures. The importance of learning Hebrew is exemplified in the well-known framework of "ulpans," run all year long under the joint auspices of the Ministry of Immigrant Absorption, the Ministry of Education, and the Jewish Agency for Israel.

In this study, we examined the affect of identification with the target society/culture (Jewish/lsraeli) and mastery of language skills (Hebrew) on the heaviness of accent developed by FSU immigrants, also taking into consideration that the age at which a person immigrates serves as a primary predictor of developing an accent.

\section{Theoretical Background Identity}

"Identity" was traditionally regarded as a stable, fixed entity within an individual that affects his actions and understanding of the world around him and is uninfluenced by external context (Marx, 2006), but is increasingly understood as fluid and dynamic, based on myriad interactions-sociological, psychological, cultural, etc. (Norton, 2000). This study focuses specifically upon the ethnic facet of identity. While ethnic identity includes a broad range of elements (Goldberg \& Noels, 2006), it is generally assumed to consist of a subjective sense of belonging to a certain ethnic group (Goldberg \& Noels, 2006), and deriving a sense of wellbeing from a positive attitude towards that collective (Phinney et al., 2001). Two central models have been proposed over the past decade to define and measure identity, although they share a uniform theoretical basis (Phinney, 1990). According to the psycho-sociological approach, it is comprised of a sense of belonging to a group (Phinney, 1992), while the developmental theory regards it as a process of probing one's ethnic identity (Erikson, 1968).

Language is frequently regarded as the principal element in the formation of social identity and articulation of the sense of belonging to a social group (Miller, 2000; Lippi-Green, 1997). Thus Kramsch, for example, regards learning acquisition as a process that informs the learner's social identity, social function, and voice, and identity as a product of the interaction between various components of the self.

Ethnic identity tendd to receive greater significance when the group is a minority (Bailey, 2000). Lambert (1975) identifies two links between language and identity that are determined by the socio-cultural dominance of the relevant language group:

a) "Subtractive bilingualism"-when the members of the ethno-lingual minority master the language of the dominant language group which, in overriding their original identity, leads to negative feelings towards their native language and culture.

b) "Additive bilingualism"-when members of the dominant language group master the language of the minority without substituting it for their own language or culture.

Identity is inseparable from the context of the social interaction within which it is formed (Goldberg \& Noels, 2006). Given that expectations relating to ethnic identity change according to the inter-group relations, ethnicity is in a perpetual state of social negotiation. Where identity is forged as part and parcel of linguistic negotiations, the degree of identification with the group as a whole depends upon the context in which the interaction occurs and the normative expectations of the situation.

Language is frequently regarded as a the key element in the construction of identity amongst members of a group, many viewing the link between language and identity as being indivisible. According to the prevalent theory, language represents social identity and membership in a group, constituting the most prominent way of grounding social identity. Identity is thus very closely tied to the sense of belonging—of being an "insider" (Miller, 2000).

Ethnic identity comprises one stratum within an individual's general identity, which is composed of a network of mobile processes. Although ethnic identity is frequently adduced for purposes of classification, for the majority of people it only forms one aspect of their identity (Miller, 2000). 
For the immigrant, language poses his greatest challenge, constantly facing him with the knowledge that it constitutes the primary tool for assimilating into the new society/culture-while simultaneously demanding that he relinquish the identity formed by his mother tongue. If he wishes to retain his identity while integrating into the target society, he must seek to preserve his own language while acquiring that spoken in his new country of residence. Immigration is frequently accompanied by an attempt to establish a cultural community in the target society-an act intended to preserve identity while ensuring social and political mobility (Al-Haj, 2002).

FSU immigrants in Israel correspondingly seek to preserve their ethnic and cultural identity while acculturating within Israeli society. This is evident in the strikingly close cultural ties within the FSU community, same-community marriages, ethnic sources of knowledge, and strong desire to retain their ethnicity and culture-Russian identity constituting a central component of their self-identification (Al-Haj, 2002). To avoid losing their Russian identity, FSU immigrants take pains to preserve the "cultural baggage" they bring with them from their country of origin (Olshtain \& Kotik, 2000).

In the past, new immigrants in Israel were compelled to assimilate within Israeli society. Over the course of time, however- especially from the beginning of the 1990s-Israeli society has become far more diverse and pluralistic. The creation of immigration concentrations - which have, to a large degree, turned into closed social communities-has made assimilation far less possible. Similarly, many Russian-speaking FSU immigrants possess a particularly high cultural selfimage and are unwilling to exchange their original identity for Israeli identity: they maintain a strong loyalty to the Russian language and culture, while also cultivating inter-cultural bridging mechanisms that demonstrate their view of themselves as partners in a dialogue rather than immigrants who must integrate into mainstream Israeli society (Cohen, 2001).

The use of the Russian mother tongue thus serves as a significant tool for preserving identity, constituting a type of "defense mechanism" against full assimilation into Israeli society. In light of Berry's theory of "acculturation"-which identifies four aspects of immigrant identity: integration, separation, assimilation, and marginalization-Horenczyk (2000) argues that the Russian immigrant chooses to combine his Russian and Israeli identities (integration) in order to preserve his primary identity (Russian). According to Guiora et al., linguistic identity is capable of concretizing the close link between language and identity. Within the permeability of the borders of this "language ego," he argues, accent is "the most salient aspect ... the hardest to penetrate (to acquire in a new language), the most difficult to lose (in one's own)" (1972: 421-422). Pronunciation represent a person's identity, and adults find it far harder to relinquish their first identity and/or adopt another. With respect to the FSU immigrants in Israel, the majority appear to have adopted an integrative strategy for becoming part of Israeli society without abandoning their culture of origin.

Flege (1987) contends that the degree to which the first language is used affects the heaviness of L2 accent, continued mother tongue usage impairing the ability to develop the phonological production necessary for preventing the acquisition of an L2 accent. This circumstance points to a mediating link between identity and accent, spoken Russian-as an act attesting to an integrative-identity approach-contributing to the acquisition of an L2 accent.

\section{Language Skills}

The definition of language as a "social force" has become more relevant in recent years than at any other time in the past, with language skills forming one of the key elements in establishing status and social mobility within the developed world (Fairclough, 1989). While it is presumed that one's mother tongue enables the performance of these functions in a monolingual country, in today's reality if that language is not English-the most prevalent language of wider communication-acquisition of another international language becomes vital. Social mobility and economic advancement frequently demand English language skills in addition to one's mother tongue (Olshtain \& Kotik, 2000). The need for an additional language does not weaken usage of the mother tongue, but the majority of educated people across the world employ English as well as their native language.

For the immigrant, acquisition of the target language is crucial, forming the sole way of achieving social mobility in monolingual countries (Olshtain \& Kotik, 2000).

Studies have demonstrated that language skills are also closely associated with income level (Chiswick \& Miller, 1995), as mastery of a language enhances the ability to enter the labor market with respect to both finding work and gaining employment commensurate with one's personal skills (Chiswick \& Miller, 1998).

In the sociolinguistic literature, language skills and the use of language form two separate entities (Fishman, 1986). Language acquisition is a broad social phenomenon of integration within a new society, being affected not only by the characteristics of the immigrants but also by contextual factors that shape the mutual relations between the environment and society. These factors include elements that existed prior to immigration and those that are present upon entering the new society. In this sense, the motivation of the immigrants and the receiving society to absorb them are influenced by a number of factors operating simultaneously and reciprocally.

Immigrants' acquisition of the local language also has an impact upon the social response towards them. Numerous studies indicate that part of the negative feeling of native-born citizens towards immigrants derives from the assumption that the latter do not want-or are unable - to learn the local language (Espenshade \& Calhoun, 1993), and that the immigrant weighed the pros and cons of doing so. Factors such as how old the person is when he immigrates, how long he has been in the country, and his educational and economic levels all affect the decision.

Other factors, such as the size and geographic distance within the immigrant community also play a role (Chiswick, 1986). When a relatively large community exists whose members live in close proximity to one another, the 
need to master the local language becomes less critical. When immigrants are surrounded by a populace speaking their own language, on the other hand, they feel less pressure to learn the local language. Acquiring the local language is imperative for the individual immigrant who, if he wishes to live a social life and make ties with his environment, must find ways to overcome the linguistic barrier. Thus, for example, Israeli Arabs tend to learn Hebrew from a young age and become fluent speakers (Abu-Rabia \& Siegel, 2003).

People who are forced to immigrate rather than choosing to do so voluntarily will regard themselves as temporary residents in their new country and thus seek to preserve their native language and culture while eschewing the local language and culture. In contrast, those who choose to immigrate generally possess a positive attitude towards the target country and are therefore more willing and ready to learn the local language.

Fishman (1986) adduces what he calls "domains of language behavior"-a concept that relates to the speaker, listener, and sphere in which the communication occurs. The immigrant can be expected to use a separate language for different contexts-family, friends, religion, education, employment, and government, etc. The original language will serve him in unofficial encounters, and the newly-acquired local language will be confined to more official settings. Studies conducted in Australia have demonstrated that immigrants use their native language at home or at unofficial events. Russian immigrants attest that Russian remains their preferred language for conversations regarding serious matters and emotions (Garner, 1988). While a speaker uses language as a reaction to the place and situation in which he finds himself, those who are bilingual will prefer to use their mother tongue whenever possible, particularly in their "intimate" environment.

The fact that the mother tongue continues to serve people for a long period after they have acquired the local language suggests that a distinction needs to be made between sociological and psychological factors. Sociological factors include the language that resides in the brain of the speaker who attempts to make sense of the world around him and communicate with people speaking another language. Psychological factors refer to languages found within the collective, and such issues as where and when language is used and why.

The sociolinguist approach stresses the significance of the various domains the speaker inhabits and the need of preserving language. Numerous studies indicate that a positive attitude towards language and motivation are important tools in L2 acquisition (Gardner, Margoret, \& Tremblay, 1999). An individual's willingness to engage in mutual relations with his surroundings also serves as a key factor in the acquisition of language skills. A favorable stance towards the local populace is also closely linked to readiness to learn the language, thereby influencing self-understanding of the level of one's skills (Gardner, Margoret, \& Tremblay, 1999).

A study conducted by Mesch (2003) found that FSU immigrants used L2 primarily due to force of circumstancein particular, the need to deal with bureaucracy. Since mastery of a language does not necessarily equate its use, the FSU immigrants only use their new language when absolutely necessary, preferring their native tongue wherever possible. Like other immigrants (Liang, 2006) who demonstrate a split between their two loyalties, these immigrants also tend to preserve their former language and culture (Abu-Rabia, 1999), opening themselves up less to the language and culture of the receiving society.

Some scholars contend that language skills do not necessarily intimate any link between the speaker and his place of residence and the degree of faithfulness he displays to either his society of origin or the target society. Linguistic mastery can occur on various levels (Lee, 2002). Frequently, language skills are acquired merely out of need rather than due to any positive or negative attitude towards the target country.

Fabbri \& Dustmann (2003) have shown that the most critical factor in acquiring skills in the local language is entry into the work market, since the chances of receiving suitable employment are far greater when the person is fluent in the language. People seeking jobs thus make greater efforts to improve their spoken and written skills in the local language.

According to some scholars, in addition to his ability to meet the demands made on him by the new country and become a productive member of society, supporting himself with dignity and seeking the possibility of social mobility, an immigrant's socio-economic status also serves as an indicator of the level of acclimatization he will achieve in his new home (Remennick, 2003). The latter study indicates that L2 acquisition constitutes the key to economic success and social integration. Despite the fact that the FSU immigrants can meet their own needs in an environment in which the local language is spoken, those with a limited knowledge of Hebrew are culturally alienated from general society.

A study examining the link between the length of stay in the target country and language skills found that those of younger immigrants increased the longer they spent in their new home, while older immigrants-fathers in particularexhibited no significant improvement (Remennick, 2004).

Language thus constitutes an inseparable part of the varied aspects of daily life. Numerous studies have presened data that link FSU immigrants' language mastery, fluency, and/or bilingualism with linguistic and economic integration into Israeli society (Chiswick, 2001). In a longitudinal study, Menahem \& Gajst (2001) found that language mastery increased over time and a positive connection to obtain this factor and professional and social integration.

Kramsch's 2001 study examined literacy, equality, and attitudes towards the immigrant learner, highlighting the paradoxes inherent in the policies of countries like Israel, which make efforts to assimilate immigrants while also recognizing the rights of minority groups to preserve their own language and heritage.

Although language plays a key role in designating ethnic identification, no distinction is made in the literature between minority groups and immigrants. Giles \& Coupland (1991) identify "four reasons for the salience of language in 
ethnic relations: language is often a criteria attribute of group membership, an important cue for ethnic categorization, an emotional dimension of identity, and a means of facilitating in group cohesion" (p. 96).

The cognition and motivation embedded in ethno-linguistic behavior are not dependent upon the social context. To the extent that two groups differ in size and status, the majority group will tend to discriminate against the minority group-including its language (Sachdev \& Bourhis, 1984)

The power of groups in a given space shapes the variety of linguistic forms used, "speakers describing or representing the actions of self or others along four categories of verbs and/or adjectives that vary in terms of their concreteness, situational orientation, objectivity, and evaluative nature" (p. 349). Attitudes towards language derive from the fact that it forms an inseparable part of group identity, constituting a significant component of intergroup behavior. An attitude is a mental image that affects the processing of information, thereby helping to guide and direct behavior at a given time and in a specific context (Eagly \& Chaiken, 1993).

Attitudes towards language include an emotional/motivational element (in relation to its status and to the intergroup framework), a cognitive component (beliefs regarding its speakers), and a behavioral aspect (intentions/acts relating to its knowledge). The emotional factor is the first to appear developmentally.

Ethnic attitudes consolidate around the age of four, in parallel with an attitude towards the self, being defined as a presupposition grounding a positive or negative response towards people belonging to another ethnic group (Aboud \& Skerry, 1984). Language is a practical expression of ethnic difference, and attitudes towards it, its use and its speakers reflect ethnic difference (Fishman, 1972).

Attitudes towards language reflect a social understanding that is unrelated to objective rational or aesthetic values. Numerous studies indicate that a link exists between attitudes towards language and its use. Giles (1977) contends that learning the language spoken by another group reflects a willingness to accommodate the views and values held by its members, and Gardner (1979) defines L2 acquisition as the acquisition of the symbolic elements of another ethnolinguistic community.

Clément (1980) points to the link between L2 acquisition and the two antithetical motivations within the theory of social identity (Tajfel \& Turner, 1979) — the need to belong and be assimilated vs. the fear of losing one's unique identity.

Giles \& Byrne's (1982) model associates the various motivations deriving from the complexity of social identity with the gaps in ethnolinguistic essentiality, mapping the factors predicting the acquisition of the dominant language amongst ethnic minority groups.

Schumann (1978) identifies two critical factors that affect L2 acquisition: social distance-or the degree of affinity one feels with a community speaking a specific language-and psychological distance, or the degree of emotional comfort and motivation attendant upon the learning process.

Gardner (1975) adduces two types of motivation: integrative-deriving from an interest in the culture and language - and instrumental, stemming from social or professional needs.

In the present study, we examined the question of whether linguistic competence decreases the possibility of developing an accent and whether broad linguistic knowledge predicts this circumstance.

\section{The Critical Age and Developing an Accent}

The idea that an ideal biological age exists for $\mathrm{L} 2$ acquisition that prevents adults from being able to master it on the same level as their mother tongue originates in a theory proposed in 1959 and developed by Lenneberg (1967). This theory has been examined and tested by various scholars over the years (Scovel, 2003), and repeatedly confirmed on the basis of behavioral evidence (Hakuta, Bialystok, \& Wiley 2003).

Although the claim that age and L2-mastery-ability are inversely related is widely accepted (Singleton, 2003), the question of whether this model precludes any possibility of later L2 acquisition is disputed. Some scholars argue that sufficient exposure to a language after the age of twelve will yield a level of language skills that is on a par with those in the mother tongue (Piller, 2002).

In 1967, Lenneberg coined the term "critical period hypothesis" (CPH), which refers to the existence of a (neuro)biological period of twelve years during which it is possible to acquire language on a mother-tongue level (Abu-Rabia \& Kehat, 2004).

Geva, Wade-Wooley, and Shany's (1997) findings demonstrate that when children acquire L2 prior to the age of six, their skills are virtually parallel to those in their native tongue.

While no consensus exists regarding the validity of the theory or the existence of a critical period for language acquisition, it is commonly accepted that the critical age is in fact crucial with respect to pronunciation skills and accent development (Komarova \& Nowak, 2001). While achieving a very high level of L2 skills, the Polish writer Joseph Conrad, for example, nonetheless retained a heavy Polish accent. The theory thus appears to be correct with respect to phonology.

In 1990, Long published a literature review of the way in which age is related to language acquisition, concluding that a (neuro-)biological base exists that functions as a critical period for language acquisition, after which it becomes virtually impossible to acquire L2 mother-tongue-level skills. The same study also found that morphological and syntactical 
mastery on a native-language level was possible up until the age of fifteen, the ability to acquire phonological skills on a par with those of one's mother tongue peaking at age six, whence it gradually decreases until the age of twelve. After this age, the task of acquiring L1-level phonological, morphological, and syntactical skills is impossible (Long, 1990).

The first linguistic factor to be affected by the critical age is pronunciation, with some scholars suggesting this is the only aspect to be influenced by this period. As the sole aspect of linguistic performance with a neuromuscular base, it both possesses a physical reality and requires neuromotoric involvement (Scovel, 1988). Here, too, those who begin learning after the age of twelve cannot achieve L2 mother-tongue level skills. Although children who are given protracted exposure to a language will generally acquire it more quickly, this is not the case after the critical period (Flege \& Liu, 2002).

Flege et al.'s 2006 study examined the affect of age and length of residency on the heaviness of L2 accent in immigrants. Their findings indicate that while length of residency evinced no significant influence, immigrants who arrived in their new country at a young age had milder accents than adults. These results are inconsistent with the critical-period theory, according to which accent is a function of immigration age. Some scholars thus contend that accent levels relate to the degree of exposure to a language.

In an investigation of the accent levels of speakers who studied ESL in school in comparison with those who studied ESL informally, Munro \& Mann (2005) found that no differentiated "critical period" existed during which an accent develops. Burrill (1985) examined the possibility of the existence of a "sensitive period," taking into consideration the variables of age, biology, and environment, and concluded that while no biological barrier exists preventing a person from acquiring an L2 accent, age nonetheless constitutes a significant factor-possibly due to psychological effects and a lack of willingness to take chances related to identification with the outside group amongst adults. In her view, adults can learn to speak without an accent and acquire phonological skills equally well as children, as long as they work on phonological aspects and accuracy in pronunciation.

Some scholars contend that the critical period is an environmental rather than a biological factor. Thus, for example, Flege, Yeni-Komshian, \& Liu (1999) found that some children developed an accent as a function of the school education they received in the target country.

Flege (1999) asserts that accent level is determined not by the critical period but by various other factors, such as the degree to which the individual's L1 pronunciation is good, and that the premise that a circumscribed period exists in which a person is capable of acquiring pronunciation skills is erroneous. While research findings do suggest a link between the age of exposure to a language and heaviness of accent, he argues that this relation is not to be attributed to a critical period but rather to the fact that learning pronunciation in one language makes the same task difficult in another. The degree to which a person uses L2 must also be taken into consideration, this greatly influencing his skills in this language.

\section{Research Questions}

Q1: What relation exists between the critical period for developing an L2 accent, the consolidation of national identity (Jewish Israeli), and mastery of language skills?

H1: A person with good language skills who immigrates to Israel before the critical period and identifies completely with the religion, culture, and language of his new country and identifies himself as an Israeli will acquire no L2 accent.

Q2: Does any relation exist between identity and development of an L2 accent (Hebrew)?

$\mathrm{H} 2$ : A mediating link will exist between these two factors, and extensive use of the mother tongue as an act of identification will be found to impair L2 acquisition-specifically, the ability to speak it without an accent.

\section{The Research}

\section{Sample Population}

50 FSU students whose mother tongue is Russian. The students were divided into two groups-those who had immigrated to Israel before the critical period for developing an accent (age 12, according to the literature) and those who had immigrated at a later age.

The control group consisted of 10 Hebrew-mother-tongue students who participated in accent-assessing tasks.

Length of residency in the country served as an independent variable controlled by the researcher.

Research tools. The students were tested with respect to three factors: present L2 accent, L2 language skills, and national identity.

\section{Accent. Accent was assessed via four tasks:}

a) Spontaneous conversation-telling about a movie, book, or personal experience (up to 20 minutes)

b) Reading an unfamiliar passage-an article from the Haaretz newspaper about culture (I. Samuelov, "Candy identification," 31.05,07): 
The final exhibition at Shenkar College of Engineering and Design can give visitors several hours of enjoyment, especially if they focus their attention on the sixth and seventh floors, where the work of the students graduating from the graphic design department is on display. In contrast to the projects of those in the industrial design department-whose level is inconsistent and few of which are innovative in any shape or form-the graduates from the visual communication, illustration, and interactive media track demonstrate an impressively professional level. All the participants were given tasks testing their basic skills in Hebrew:

1) Reading pseudo-words (Deutsch, 1997): Participants read nonsense words in Hebrew—such as aqla, briqa, tzun.

2) Repetition of pseudo-words: Participants repeated nonsense words in Hebrew—such as galid, qish, gdah9.

3) Phonological awareness (Shany \& Ben-Dror, 1997): Participants were asked to delete sounds from the words and then read the words aloud. For example: h9atul without the "t," shir without the "r".

4) Vocabulary-Milta (Aram, 1999): Participants were asked to choose a meaning for a word out of four options. For example: niftar-1) died; 2) left; 3) was sorry. The task is constructed on a rising difficulty scale.

5) Pronunciation fluency (linguistic illusions) (Shatil, 1997): Participants were asked to repeat a sequence of nonsense sounds as accurately as possible. The task was divided into two parts-an easy sequence and a difficult sequence.

6) Listening comprehension: Participants were asked to answer questions relating to a pre-recorded short story.

c) Reading sentences-10 sentences of between 5-10 words each, composed specifically for this study. Taken from Haaretz (31.05.07), they focus on three central fields: current affairs, culture, and sports. For example: 1) "Executives from the sports department decided on a series of emergency measures"; 2) "The Labor Party will decide how to vote during the meeting."

d) Reading unvocalized words (level 2) —reading 50 single words (Shany, Biemiller, and Dror, out of Pioneering Stage Tests, 2000) in Hebrew of various levels of difficulty. For example: morim [teachers], ratznu [we ran], tnufa [momentum].

\section{Language skills.}

National identity (Jewish/lsraeli). Identity was tested by a closed questionnaire (Teitelman, 2006) focusing on Israeli identity and aspects related to self-understanding in light of the culture, religion, and personal identity the individual adopts for himself. The questionnaire addresses the participants' views regarding society, the State, and being Israeli. It contains 23 statements, the participant being asked to mark his answer on a scale between 1 and 4 . For example: "How important is belonging to the Jewish national collective to you?" "To what degree to you feel Russian?" "To what degree do you feel Israeli?"

\section{Procedures}

The tasks were administered separately to the two research groups (before and after the critical-age period). All the participants were taped in each of the four tasks testing accent. The tapes were evaluated by five MA student assessors, native Israelis and mother-tongue Hebrew speakers (two female, three male), who were asked to assess the heaviness of the accent and rank it on a scale from 1 to 5, 1 being a very heavy accent (Hebrew definitely not being the mother tongue), 2 a strong accent, 3 a moderate accent, 4 a mild accent, and 5 no accent at all (Hebrew very likely being the mother tongue).

The participants were given four language tasks testing their phonological production and two testing their more general linguistic knowledge (vocabulary) and spoken-language understanding abilities (listening comprehension). The phonological-production tests focused on the ability to produce sounds in Hebrew according to various degrees of difficulty and the manipulation of common words.

An identity questionnaire was also administered, and participants were asked to respond to the statements on a 1-5 agreement/disagreement scale. The questions focused on national identity, relating specifically to Israeli identity, Jewish identity, and cultural identity. While the Jewish element was fixed, Israeli identity and identification with the local culture were linked to personal choice and desire to become a true part of Israeli society.

The study set out to examine the relation between Jewish/Israeli identity, language-skills mastery, and heaviness of accent. Numerous other studies have investigated the link between accent and language skills, and the critical-age period for developing an accent still constitutes the most significant factor in relation to L2 accent. This study sought to test the link between identity and pronunciation levels, after analysis in a seminar found that participants' willingness to integrate into Israeli society comprised a significant factor in their language skills and pronunciation ability.

As noted above, the uniqueness of this study lies in its addition of the "identity" variable to those items more frequently adduced (critical age and language skills). In more general terms, this link-if it exists-can point to psychological aspects in the development of $\mathrm{L} 2$ accent.

\section{Findings}


In order to analyze the data collected during the study, we conducted a number of statistical tests that facilitated assessment of the research hypotheses: an ANOVA test, t-tests, and x2 tests. The various correlations between the variables were also examined.

At the beginning, we calculated the average mean scores regarding the heaviness of accent and various language tasks according to age of immigration to Israel-including a control group, and analyzed the divergences between the three populations.

Table 1: Bidirectional difference analysis testing the divergences between the three sample populations

\begin{tabular}{|c|c|c|c|c|c|c|}
\hline & & $\begin{array}{l}\text { Sum of } \\
\text { Squares }\end{array}$ & df & $\begin{array}{l}\text { Mean } \\
\text { Squares }\end{array}$ & $\mathbf{F}$ & Sig. \\
\hline \multirow[t]{3}{*}{$\begin{array}{l}\text { Assessors' overall score- } \\
\text { accent }\end{array}$} & Between groups & 64.33 & 2 & 32.16 & 38.29 & 0.00 \\
\hline & Within groups & 47.87 & 57 & 0.84 & & \\
\hline & Total & 112.21 & 59 & & & \\
\hline \multirow[t]{3}{*}{ Unvocalized words score } & Between groups & 540.03 & 2 & 270.01 & 21.83 & 0.00 \\
\hline & Within groups & 704.81 & 57 & 12.36 & & \\
\hline & Total & 1244.85 & 59 & & & \\
\hline \multirow[t]{3}{*}{ Reading comprehension } & Between groups & 0.30 & 2 & 0.15 & 0.62 & 0.53 \\
\hline & Within groups & 13.87 & 57 & 0.24 & & \\
\hline & Total & 14.18 & 59 & & & \\
\hline \multirow[t]{3}{*}{ Pseudo-words-reading } & Between groups & 125.45 & 2 & 62.72 & 15.13 & 0.00 \\
\hline & Within groups & 236.27 & 57 & 4.14 & & \\
\hline & Total & 361.73 & 59 & & & \\
\hline \multirow[t]{3}{*}{ Pseudo-words-repetition } & Between groups & 21.48 & 2 & 10.74 & 1.84 & 0.16 \\
\hline & Within groups & 332.45 & 57 & 5.83 & & \\
\hline & Total & 353.93 & 59 & & & \\
\hline \multirow[t]{3}{*}{ Phonetic deletion } & Between groups & 21.79 & 2 & 10.89 & 2.42 & 0.09 \\
\hline & Within groups & 255.93 & 57 & 4.49 & & \\
\hline & Total & 277.73 & 59 & & & \\
\hline \multirow[t]{3}{*}{ Pronunciation fluency-easy } & Between groups & 7.03 & 2 & 3.51 & 1.88 & 0.16 \\
\hline & Within groups & 106.61 & 57 & 1.87 & & \\
\hline & $\begin{array}{l}\text { Between } \\
\text { Groups }\end{array}$ & 2.96 & 2 & 1.48 & 0.04 & 0.95 \\
\hline \multirow{2}{*}{ Pronunciation fluency-difficult } & Within groups & 1811.22 & 57 & 31.77 & & \\
\hline & Total & 1814.18 & 59 & & & \\
\hline \multirow[t]{3}{*}{ Vocabulary_Milta } & Between groups & 377.99 & 2 & 188.99 & 16.09 & 0.00 \\
\hline & Within groups & 669.34 & 57 & 11.74 & & \\
\hline & Total & 1047.33 & 59 & & & \\
\hline
\end{tabular}

In the bidirectional difference analysis conducted, a significant difference was found between the groups with respect to heaviness of accent, reading un-vocalized words, reading pseudo-words, and vocabulary level.

A post hoc test was then conducted to examine the divergences between the groups. This indicates that significant differences were found between each of the three populations in relation to the other two with respect to heaviness of accent, level of reading un-vocalized words, reading pseudo-words, and vocabulary level. 
We then calculated the mean scores according to the age of immigration. The findings demonstrate that -with the exception of difficult vocabulary - those who had immigrated before they were twelve gained the best grades in each of the language skills. The differences between the mean averages of the two independent samples were analyzed.

Table 2: Differences between the mean score of the two independent samples

\begin{tabular}{|c|c|c|c|c|c|c|c|c|c|c|}
\hline & & \multicolumn{2}{|c|}{$\begin{array}{l}\text { Levene's } \\
\text { test for } \\
\text { equality of } \\
\text { variances }\end{array}$} & \multicolumn{5}{|c|}{ t-test for equality of means } & \multirow{2}{*}{\multicolumn{2}{|c|}{$\begin{array}{l}95 \% \text { confidence } \\
\text { interval of the } \\
\text { difference }\end{array}$}} \\
\hline & & $\mathbf{F}$ & Sig. & $\mathbf{t}$ & df & $\begin{array}{l}\text { Sig. } \\
(2- \\
\text { tailed) }\end{array}$ & $\begin{array}{l}\text { Mean } \\
\text { difference }\end{array}$ & $\begin{array}{l}\text { Std. error } \\
\text { difference }\end{array}$ & & \\
\hline & & & & & & & & & Lower & Upper \\
\hline \multirow[t]{2}{*}{$\begin{array}{l}\text { Assessors' } \\
\text { overall score- } \\
\text { accent }\end{array}$} & $\begin{array}{l}\text { Equal } \\
\text { variances } \\
\text { assumed }\end{array}$ & .00 & .98 & 6.19 & 48 & .00 & 1.75 & .28 & 1.18 & 2.32 \\
\hline & $\begin{array}{l}\text { Equal } \\
\text { variances } \\
\text { not } \\
\text { assumed }\end{array}$ & & & 6.16 & 45.68 & .00 & 1.75 & .28 & 1.18 & 2.32 \\
\hline \multirow[t]{2}{*}{$\begin{array}{l}\text { Unvocalized } \\
\text { words score }\end{array}$} & $\begin{array}{l}\text { Equal } \\
\text { variances } \\
\text { assumed }\end{array}$ & 7.60 & ${ }^{*} .01$ & 5.61 & 48 & .00 & 6.01 & 1.07 & 3.86 & 8.16 \\
\hline & $\begin{array}{l}\text { Equal } \\
\text { variances } \\
\text { not } \\
\text { assumed }\end{array}$ & & & 5.40 & 34.64 & .00 & 6.01 & 1.11 & 3.75 & 8.28 \\
\hline \multirow[t]{2}{*}{$\begin{array}{l}\text { Reading } \\
\text { comprehension }\end{array}$} & $\begin{array}{l}\text { Equal } \\
\text { variances } \\
\text { assumed }\end{array}$ & 5.60 & ${ }^{*} .02$ & 1.08 & 48 & .28 & .16 & .14 & -.13 & .44 \\
\hline & $\begin{array}{l}\text { Equal } \\
\text { variances } \\
\text { not } \\
\text { assumed }\end{array}$ & & & 1.04 & 33.68 & .30 & .15 & .15 & -.14 & .46 \\
\hline \multirow[t]{2}{*}{$\begin{array}{l}\text { Pseudo-words- } \\
\text { reading }\end{array}$} & $\begin{array}{l}\text { Equal } \\
\text { variances } \\
\text { assumed }\end{array}$ & 4.58 & ${ }^{*} .03$ & 4.13 & 48 & .00 & 2.54 & .61 & 1.30 & 3.78 \\
\hline & $\begin{array}{l}\text { Equal } \\
\text { variances } \\
\text { not } \\
\text { assumed }\end{array}$ & & & 3.99 & 36.19 & .00 & 254 & .63 & 1.25 & 3.84 \\
\hline \multirow[t]{2}{*}{$\begin{array}{l}\text { Pseudo-words- } \\
\text { repetition }\end{array}$} & $\begin{array}{l}\text { Equal } \\
\text { variances } \\
\text { assumed }\end{array}$ & 7.69 & ${ }^{*} .01$ & 1.61 & 48 & .11 & 1.20 & .74 & -.29 & 2.70 \\
\hline & $\begin{array}{l}\text { Equal } \\
\text { variances } \\
\text { not } \\
\text { assumed }\end{array}$ & & & 1.49 & 22.99 & .14 & 1.20 & .80 & -.46 & 2.87 \\
\hline \multirow[t]{2}{*}{$\begin{array}{l}\text { Phonetic } \\
\text { deletion }\end{array}$} & $\begin{array}{l}\text { Equal } \\
\text { variances } \\
\text { assumed }\end{array}$ & .42 & .51 & .29 & 48 & .76 & .19 & .64 & -1.10 & 1.49 \\
\hline & $\begin{array}{l}\text { Equal } \\
\text { variances } \\
\text { not } \\
\text { assumed }\end{array}$ & & & .29 & 45.55 & .76 & .19 & .65 & -1.11 & 1.50 \\
\hline $\begin{array}{l}\text { Pronunciation } \\
\text { fluency- easy }\end{array}$ & $\begin{array}{l}\text { Equal } \\
\text { variances }\end{array}$ & 6.22 & ${ }^{*} .01$ & 1.20 & 48 & .23 & .39 & .32 & -.26 & 1.06 \\
\hline
\end{tabular}




\begin{tabular}{|c|c|c|c|c|c|c|c|c|c|c|}
\hline & & $\begin{array}{l}\text { Leve } \\
\text { test } \\
\text { eque } \\
\text { varie }\end{array}$ & & t-tes & for equ & lity of $m$ & ans & & & \\
\hline & & $\mathbf{F}$ & Sig. & $t$ & df & $\begin{array}{l}\text { Sig. } \\
(2- \\
\text { tailed) }\end{array}$ & $\begin{array}{l}\text { Mean } \\
\text { difference }\end{array}$ & $\begin{array}{l}\text { Std. error } \\
\text { difference }\end{array}$ & \multicolumn{2}{|c|}{$\begin{array}{l}95 \% \text { confidence } \\
\text { interval of the } \\
\text { difference }\end{array}$} \\
\hline & & & & & & & & & Lower & Upper \\
\hline & assumed & & & & & & & & & \\
\hline & $\begin{array}{l}\text { Equal } \\
\text { variances } \\
\text { not } \\
\text { assumed }\end{array}$ & & & 1.11 & 22.48 & .27 & .39 & .35 & -.34 & 1.13 \\
\hline \multirow[t]{2}{*}{$\begin{array}{l}\text { Pronunciation } \\
\text { fluency- } \\
\text { difficult }\end{array}$} & $\begin{array}{l}\text { Equal } \\
\text { variances } \\
\text { assumed }\end{array}$ & .57 & .45 & -.31 & 48 & .75 & -.48 & 1.54 & -3.59 & 2.62 \\
\hline & $\begin{array}{l}\text { Equal } \\
\text { variances } \\
\text { not } \\
\text { assumed }\end{array}$ & & & -.31 & 47.77 & .75 & -.48 & 1.53 & -3.57 & 2.59 \\
\hline \multirow{3}{*}{$\begin{array}{l}\text { Vocabulary- } \\
\text { Milta }\end{array}$} & Equal & .01 & .94 & 3.96 & 48 & .00 & 4.11 & 1.04 & 2.02 & 6.21 \\
\hline & $\begin{array}{l}\text { variances } \\
\text { assumed }\end{array}$ & & & & & & & & & \\
\hline & $\begin{array}{l}\text { Equal } \\
\text { variances } \\
\text { not } \\
\text { assumed }\end{array}$ & & & 3.94 & 46.06 & .00 & 4.11 & 1.04 & 2.01 & 6.22 \\
\hline & & & & & & & & & & \\
\hline
\end{tabular}

Table 2 presents the findings regarding the hypothesis that immigration during the period before/after the critical age affects language skills. A t-test was conducted on the dependent samples. The result indicate a significant difference between the mean averages with respect to reading un-vocalized words, reading comprehension, reading and repeating pseudo-words, and the difficult pronunciation fluency test. In each of these fields, the mean average of those who had immigrated before the age of twelve was significantly higher.

The hypothesis that heaviness of accent affects language skills was investigated via a t-test of the dependent samples.

Table 3: Affect of strength of accent on language skills

\begin{tabular}{|c|c|c|c|c|c|c|c|c|c|}
\hline & & $\begin{array}{l}\text { Levene's test for } \\
\text { equality of variance }\end{array}$ & \multicolumn{5}{|c|}{ t-test for equality of means } & \multirow{2}{*}{\multicolumn{2}{|c|}{$\begin{array}{l}95 \% \\
\text { confidence } \\
\text { interval of the } \\
\text { difference }\end{array}$}} \\
\hline & & \multirow[t]{2}{*}{$\mathbf{F}$} & \multirow[t]{2}{*}{$t$} & \multirow[t]{2}{*}{ df } & \multirow[t]{2}{*}{$\begin{array}{l}\text { Sig. } \\
\text { (2- } \\
\text { tailed) }\end{array}$} & \multirow[t]{2}{*}{$\begin{array}{l}\text { Mean } \\
\text { difference }\end{array}$} & \multirow[t]{2}{*}{$\begin{array}{l}\text { Std. error } \\
\text { difference }\end{array}$} & & \\
\hline & & & & & & & & Lower & Upper \\
\hline \multirow[t]{2}{*}{$\begin{array}{l}\text { Assessors' } \\
\text { overall score } \\
\text { accent }\end{array}$} & $\begin{array}{l}\text { Equal } \\
\text { variances } \\
\text { assumed }\end{array}$ & .22 & 2.13 & 58 & .03 & 1.23 & .57 & .07 & 2.38 \\
\hline & $\begin{array}{l}\text { Equal } \\
\text { variances } \\
\text { not } \\
\text { assumed }\end{array}$ & & 2.01 & 6.00 & .09 & 1.23 & .61 & -.26 & 2.72 \\
\hline \multirow[t]{2}{*}{$\begin{array}{l}\text { Unvocalized } \\
\text { words score }\end{array}$} & $\begin{array}{l}\text { Equal } \\
\text { variances } \\
\text { assumed }\end{array}$ & .48 & 1.48 & 58 & .14 & 2.90 & 1.95 & -1.00 & 6.82 \\
\hline & $\begin{array}{l}\text { Equal } \\
\text { variances } \\
\text { not }\end{array}$ & & 1.79 & 6.91 & .11 & 2.90 & 1.62 & -.93 & 6.74 \\
\hline
\end{tabular}




\begin{tabular}{|c|c|c|c|c|c|c|c|c|c|c|}
\hline & & \multicolumn{2}{|c|}{$\begin{array}{l}\text { Levene's test for } \\
\text { equality of variance }\end{array}$} & \multicolumn{7}{|c|}{ t-test for equality of means } \\
\hline & & \multirow[t]{2}{*}{$\mathbf{F}$} & \multirow[t]{2}{*}{ Sig. } & \multirow[t]{2}{*}{$\mathbf{t}$} & \multirow[t]{2}{*}{ df } & \multirow[t]{2}{*}{$\begin{array}{l}\text { Sig. } \\
\text { (2- } \\
\text { tailed) }\end{array}$} & \multirow[t]{2}{*}{$\begin{array}{l}\text { Mean } \\
\text { difference }\end{array}$} & \multirow[t]{2}{*}{$\begin{array}{l}\text { Std. error } \\
\text { difference }\end{array}$} & \multicolumn{2}{|c|}{$\begin{array}{l}95 \% \\
\text { confidence } \\
\text { interval of the } \\
\text { difference }\end{array}$} \\
\hline & & & & & & & & & Lower & Upper \\
\hline & assumed & & & & & & & & & \\
\hline \multirow[t]{2}{*}{$\begin{array}{l}\text { Reading } \\
\text { comprehension }\end{array}$} & $\begin{array}{l}\text { Equal } \\
\text { variances } \\
\text { assumed }\end{array}$ & .33 & .56 & -.26 & 58 & .79 & -.05 & .21 & -.48 & .37 \\
\hline & $\begin{array}{l}\text { Equal } \\
\text { variances } \\
\text { not } \\
\text { assumed }\end{array}$ & & & -.30 & 6.80 & .76 & -.05 & .18 & -.48 & .37 \\
\hline \multirow[t]{2}{*}{$\begin{array}{l}\text { Pseudo- } \\
\text { words- } \\
\text { reading }\end{array}$} & $\begin{array}{l}\text { Equal } \\
\text { variances } \\
\text { assumed }\end{array}$ & .25 & .61 & 2.03 & 58 & .04 & 2.11 & 1.03 & .03 & 4.19 \\
\hline & $\begin{array}{l}\text { Equal } \\
\text { variances } \\
\text { not } \\
\text { assumed }\end{array}$ & & & 1.87 & 5.94 & 1 & 2.11 & 1.12 & -.64 & 4.87 \\
\hline \multirow[t]{2}{*}{$\begin{array}{l}\text { Pseudo- } \\
\text { words- } \\
\text { repetition }\end{array}$} & $\begin{array}{l}\text { Equal } \\
\text { variances } \\
\text { assumed }\end{array}$ & .24 & .62 & .73 & 58 & .46 & .77 & 1.05 & -1.34 & 2.89 \\
\hline & $\begin{array}{l}\text { Equal } \\
\text { variances } \\
\text { not } \\
\text { assumed }\end{array}$ & & & .98 & 7.51 & .35 & .77 & .79 & -1.07 & 2.62 \\
\hline \multirow[t]{2}{*}{$\begin{array}{l}\text { Phonetic } \\
\text { deletion }\end{array}$} & $\begin{array}{l}\text { Equal } \\
\text { variances } \\
\text { assumed }\end{array}$ & 2.18 & .14 & 2.57 & 58 & .01 & 2.29 & .89 & .51 & 4.08 \\
\hline & $\begin{array}{l}\text { Equal } \\
\text { variances } \\
\text { not } \\
\text { assumed }\end{array}$ & & & 1.93 & 5.56 & .10 & 2.29 & 1.18 & -.66 & 5.25 \\
\hline \multirow[t]{2}{*}{$\begin{array}{l}\text { Pronunciation } \\
\text { fluency- easy }\end{array}$} & $\begin{array}{l}\text { Equal } \\
\text { variances } \\
\text { assumed }\end{array}$ & .59 & 4 & -.33 & 58 & .73 & -.20 & .60 & -1.40 & 1.00 \\
\hline & $\begin{array}{l}\text { Equal } \\
\text { variances } \\
\text { not } \\
\text { assumed }\end{array}$ & & & -.78 & 24.54 & .43 & -.20 & .25 & -.73 & .33 \\
\hline \multirow[t]{2}{*}{$\begin{array}{l}\text { Pronunciation } \\
\text { fluency- } \\
\text { difficult }\end{array}$} & $\begin{array}{l}\text { Equal } \\
\text { variances } \\
\text { assumed }\end{array}$ & .66 & .41 & -.56 & 58 & .57 & -1.35 & 2.40 & -6.15 & 3.45 \\
\hline & $\begin{array}{l}\text { Equal } \\
\text { variances } \\
\text { not } \\
\text { assumed }\end{array}$ & & & -.69 & 7.01 & .51 & -1.35 & 1.94 & -5.95 & 3.25 \\
\hline \multirow[t]{2}{*}{$\begin{array}{l}\text { Vocabulary- } \\
\text { Milta }\end{array}$} & $\begin{array}{l}\text { Equal } \\
\text { variances } \\
\text { assumed }\end{array}$ & .01 & .94 & 2.10 & 58 & .04 & 3.70 & 1.76 & .17 & 7.23 \\
\hline & $\begin{array}{l}\text { Equal } \\
\text { variances } \\
\text { not }\end{array}$ & & & 2.00 & 6.03 & .09 & 3.70 & 1.84 & -.82 & 8.22 \\
\hline
\end{tabular}


Levene's test for

equality of variance

$\mathbf{F}$ t-test for equality of means

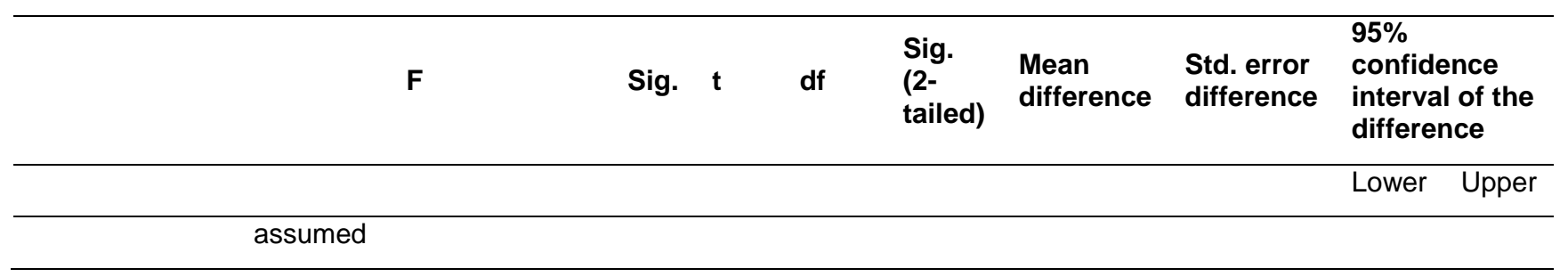

Table 3 indicates no relation between heaviness of accent and language ability, $p>0.005$ in each of the fields tested. We then calculated the mean average scores of Jewish identity according to age of immigration, examining it as a function of the age of immigration.

Table 4: Affect of immigration age on identity adoption

\begin{tabular}{|c|c|c|c|c|c|c|c|c|c|c|}
\hline & & \multicolumn{2}{|c|}{$\begin{array}{l}\text { Levene's } \\
\text { test for } \\
\text { equality of } \\
\text { variance }\end{array}$} & \multicolumn{5}{|c|}{ t-test for equality of means } & & \\
\hline & & $\mathbf{F}$ & Sig. & $\mathbf{t}$ & df & $\begin{array}{l}\text { Sig. } \\
(2- \\
\text { tailed) }\end{array}$ & $\begin{array}{l}\text { Mean } \\
\text { differenc } \\
\text { e }\end{array}$ & $\begin{array}{l}\text { Std. error } \\
\text { difference }\end{array}$ & $\begin{array}{l}95 \% \text { confidence } \\
\text { interval of the } \\
\text { difference }\end{array}$ & \\
\hline & & & & & & & & & Lower & Upper \\
\hline \multirow[t]{2}{*}{$\begin{array}{l}\text { Jewish } \\
\text { identity }\end{array}$} & $\begin{array}{l}\text { Equal } \\
\text { variances } \\
\text { assumed }\end{array}$ & .10 & .75 & -.87 & 48 & .38 & -.15 & .17 & -.51 & .20 \\
\hline & $\begin{array}{l}\text { Equal } \\
\text { variances } \\
\text { not } \\
\text { assumed }\end{array}$ & & & -.88 & $\begin{array}{l}47.7 \\
7\end{array}$ & .38 & -.15 & .17 & -.50 & .19 \\
\hline \multirow[t]{2}{*}{$\begin{array}{l}\text { Israeli } \\
\text { identity }\end{array}$} & $\begin{array}{l}\text { Equal } \\
\text { variances } \\
\text { assumed }\end{array}$ & .52 & .47 & 2.73 & 48 & .00 & .40 & .14 & .10 & .70 \\
\hline & $\begin{array}{l}\text { Equal } \\
\text { variances } \\
\text { not } \\
\text { assumed }\end{array}$ & & & 2.70 & $\begin{array}{l}43.6 \\
3\end{array}$ & .01 & & .15 & .10 & .71 \\
\hline \multirow[t]{2}{*}{$\begin{array}{l}\text { Russian } \\
\text { identity }\end{array}$} & $\begin{array}{l}\text { Equal } \\
\text { variances } \\
\text { assumed }\end{array}$ & .37 & .54 & -.99 & 48 & .32 & -.23 & .23 & -.69 & .23 \\
\hline & $\begin{array}{l}\text { Equal } \\
\text { variances } \\
\text { not } \\
\text { assumed }\end{array}$ & & & -1.00 & $\begin{array}{l}47.4 \\
6\end{array}$ & .32 & -.23 & .23 & -.69 & .23 \\
\hline \multirow[t]{2}{*}{$\begin{array}{l}\text { Conflict } \\
\text { ethos }\end{array}$} & $\begin{array}{l}\text { Equal } \\
\text { variances } \\
\text { assumed }\end{array}$ & .55 & .46 & .27 & 48 & .78 & .06 & .23 & -.40 & .52 \\
\hline & $\begin{array}{l}\text { Equal } \\
\text { variances } \\
\text { not } \\
\text { assumed }\end{array}$ & & & .27 & $\begin{array}{l}44.3 \\
8\end{array}$ & .78 & .06 & .23 & -.40 & .53 \\
\hline
\end{tabular}

The findings presented in Table 4 demonstrate that immigration age exerts no influence on the adoption of identity (whatever this may be).

We then examined the independent variables (immigration age [under/over 12]) and Israeli identity. 
Table 5: Mean averages, size, and sample for each of the values of the independent variables

\begin{tabular}{lllll}
\hline $\begin{array}{l}\text { Dichotomous } \\
\text { immigration age }\end{array}$ & Israeli identity & Mean & SD & N \\
\hline \multirow{3}{*}{ Up to age 12 } & Below median & 3.5 & 1.34 & 9 \\
& Above median & 4.30 & 0.59 & 18 \\
& Total & 4.03 & 0.97 & 27 \\
Over age 12 & Below median & 2.40 & 1.17 & 16 \\
& Above median & 2.00 & 0.57 & 7 \\
Total & Total & 2.28 & 1.03 & 23 \\
& Below median & 2.80 & 1.32 & 25 \\
& Above median & 3.66 & 1.20 & 25 \\
& Total & 3.23 & 1.32 & 50 \\
\hline
\end{tabular}

Table 6: The relationship between accent and immigration age and accent and

\begin{tabular}{llllll}
\multicolumn{5}{c}{ Israeli identity } \\
\hline Dependent variable: Assessors' overall score-accent \\
\hline Source & $\begin{array}{l}\text { Type III sum of } \\
\text { squares }\end{array}$ & $\mathbf{d f}$ & $\begin{array}{l}\text { Mean } \\
\text { square }\end{array}$ & $\mathbf{F}$ & Sig. \\
\hline $\begin{array}{l}\text { Corrected } \\
\text { model }\end{array}$ & 42.92 & 3 & 14.30 & 15.24 & .00 \\
Intercept & 400.85 & 1 & 400.85 & 427.04 & .00 \\
Over age 12 & 31.06 & 1 & 31.06 & 33.09 & .00 \\
isden-2 & .42 & 1 & .42 & 0.45 & .50 \\
Over age 12 & 3.94 & 1 & 3.94 & 4.20 & .04 \\
isden-2 & 43.17 & 46 & .93 & & \\
Error & 607.75 & 50 & & & \\
Total & 86.10 & 49 & & & \\
Corrected total & & 40 & & &
\end{tabular}

A bidirectional difference analysis found a significant principal effect of over-age-12 immigration age $(F=33.090, p=0.00)$ upon heaviness of accent-as well as for interaction between Israeli identity and immigration age $(F=4.205, p=0.046)$.

Table 7: Affect of immigration age and Israeli identity on immigrant's vocabulary

\begin{tabular}{lllll}
\hline $\begin{array}{l}\text { Dichotomous } \\
\text { immigration age }\end{array}$ & Israeli identity & Mean & SD & N \\
& & & & \\
\hline \multirow{3}{*}{ Up to age 12 } & Under median & 13.00 & 4.35 & 9 \\
& Over median & 15.72 & 2.86 & 18 \\
& Total & 14.81 & 3.59 & 27 \\
& Under median & 9.94 & 3.75 & 16 \\
Over age 12 & Over median & 12.43 & 3.35 & 7 \\
& Total & 10.70 & 3.74 & 23
\end{tabular}




\begin{tabular}{lllll} 
& Under median & 11.04 & 4.16 & 25 \\
Total & Over median & 14.80 & 3.30 & 25 \\
& Total & 12.92 & 4.17 & 50 \\
\hline
\end{tabular}

Table 8: Affect of immigration age on Israeli identity and vocabulary

\begin{tabular}{llllll}
\hline Source & Type III sum of squares & df & Mean square & F & Sig. \\
\hline Corrected model & 285.41 & 3 & 95.13 & 7.67 & ${ }^{*} .00$ \\
Intercept & 7015.71 & 1 & 7015.71 & 565.92 & ${ }^{*} .00$ \\
Over age 12 & 108.59 & 1 & 108.59 & 8.76 & ${ }^{*} .05$ \\
isden-2 & 73.05 & 1 & 73.05 & 5.89 & ${ }^{*} 0.01$ \\
Over age 12 *isden-2 & .14 & 1 & .14 & .01 & .91 \\
Error & 570.26 & 46 & 12.39 & & \\
Total & 9202.0 & 50 & & & \\
Corrected total & 855.68 & 49 & & & \\
\hline
\end{tabular}

A bidirectional difference analysis conducted indicated a significant principal relation between immigration age and vocabulary level $(F=8.760, p=0.05)$ and between Israeli identity, immigration age, and heaviness of accent. No interaction existed between the independent variables because the immigration-age variable has a similar effect upon vocabulary for each of the categories of the independent variable Israeli identity.

Table 9: Summary of findings of all the correlations for the sample populations, including the control group

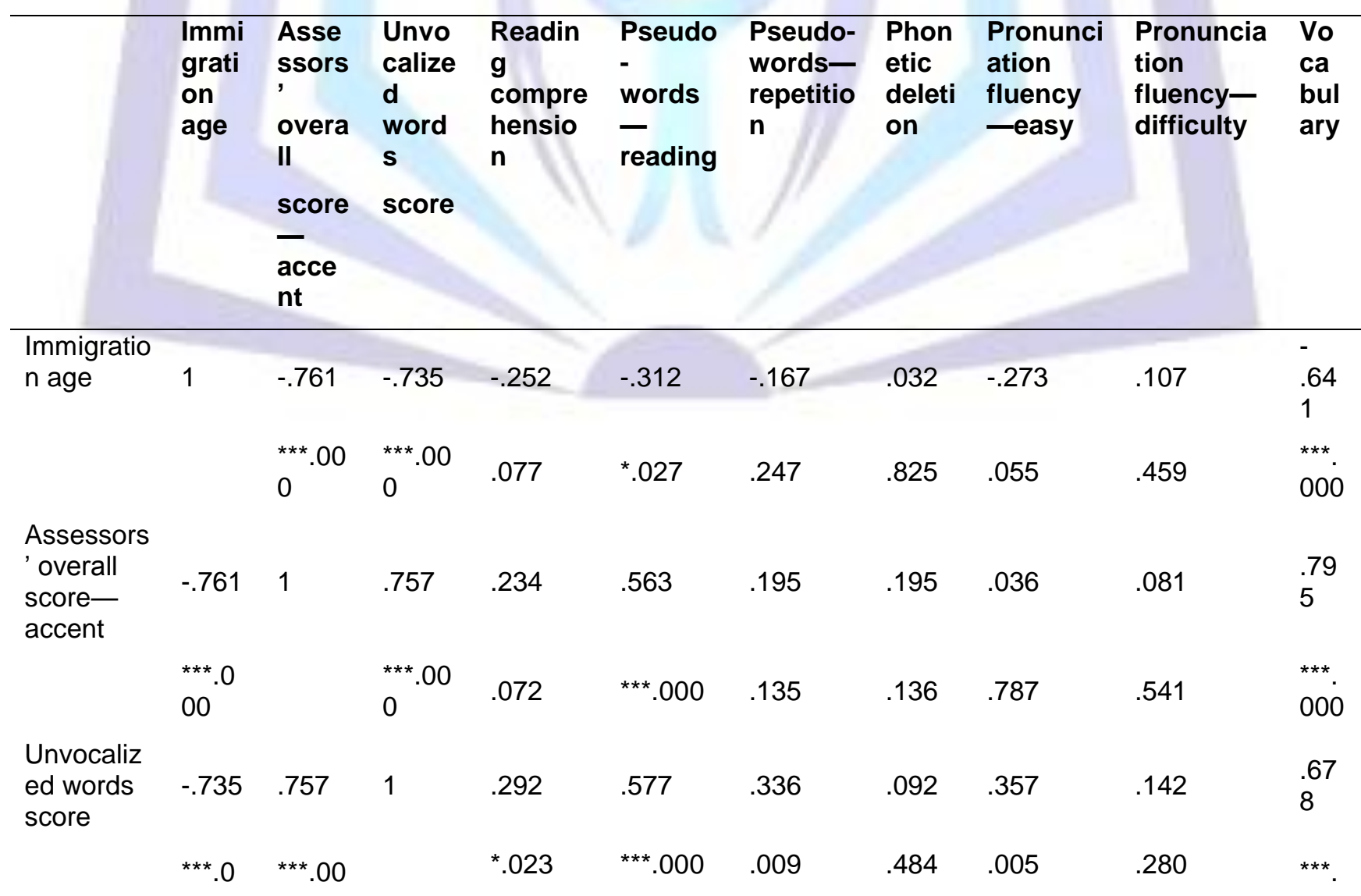




\begin{tabular}{|c|c|c|c|c|c|c|c|c|c|c|}
\hline & $\begin{array}{l}\text { Immi } \\
\text { grati } \\
\text { on } \\
\text { age }\end{array}$ & $\begin{array}{l}\text { Asse } \\
\text { ssors } \\
\text { overa } \\
\text { II } \\
\text { score } \\
\text { acce } \\
\text { nt }\end{array}$ & $\begin{array}{l}\text { Unvo } \\
\text { calize } \\
\text { d } \\
\text { word } \\
\text { s } \\
\text { score }\end{array}$ & $\begin{array}{l}\text { Readin } \\
\mathbf{g} \\
\text { compre } \\
\text { hensio } \\
\mathbf{n}\end{array}$ & $\begin{array}{l}\text { Pseudo } \\
\text { - } \\
\text { words } \\
\text { - } \\
\text { reading }\end{array}$ & $\begin{array}{l}\text { Pseudo- } \\
\text { words- } \\
\text { repetitio } \\
\text { n }\end{array}$ & $\begin{array}{l}\text { Phon } \\
\text { etic } \\
\text { deleti } \\
\text { on }\end{array}$ & $\begin{array}{l}\text { Pronunci } \\
\text { ation } \\
\text { fluency } \\
\text {-easy }\end{array}$ & $\begin{array}{l}\text { Pronuncia } \\
\text { tion } \\
\text { fluency- } \\
\text { difficulty }\end{array}$ & $\begin{array}{l}\text { Vo } \\
\text { ca } \\
\text { bul } \\
\text { ary }\end{array}$ \\
\hline & 00 & 0 & & & & & & & & 000 \\
\hline \multirow[t]{2}{*}{$\begin{array}{l}\text { Reading } \\
\text { comprehe } \\
\text { nsion }\end{array}$} & -.252 & .234 & .292 & 1 & .152 & .251 & -.066 & .260 & -.036 & $\begin{array}{l}.23 \\
5\end{array}$ \\
\hline & .077 & .072 & ${ }^{\star} .023$ & & .247 & .053 & .617 & ${ }^{*} .045$ & .783 & $\begin{array}{l}.07 \\
1\end{array}$ \\
\hline $\begin{array}{l}\text { Pseudo- } \\
\text { words- } \\
\text { reading }\end{array}$ & -.312 & .563 & .577 & .152 & 1 & .421 & .356 & .131 & .165 & $\begin{array}{l}.43 \\
1\end{array}$ \\
\hline & .027 & $0^{* \star *} .00$ & $0^{* * *} .00$ & .247 & & .0 & .005 & .321 & .207 & $\begin{array}{l}.00 \\
1\end{array}$ \\
\hline \multirow[t]{2}{*}{$\begin{array}{l}\text { Pseudo- } \\
\text { words- } \\
\text { repetition }\end{array}$} & -.167 & .195 & .336 & .251 & .421 & 1 & .002 & .118 & -.103 & $\begin{array}{l}.10 \\
7\end{array}$ \\
\hline & .247 & .135 & .009 & .053 & .001 & & .991 & .369 & .435 & $\begin{array}{l}.41 \\
4\end{array}$ \\
\hline $\begin{array}{l}\text { Phonetic } \\
\text { deletion }\end{array}$ & .032 & .195 & .092 & -.06 & .356 & .0 & 1 & .002 & .325 & $\begin{array}{l}.14 \\
2\end{array}$ \\
\hline & .825 & .136 & .484 & .617 & .005 & .991 & & .986 & ${ }^{*} .011$ & $\begin{array}{l}.28 \\
1\end{array}$ \\
\hline $\begin{array}{l}\text { Pronuncia } \\
\text { tion } \\
\text { fluency- } \\
\text { easy }\end{array}$ & -.273 & .036 & .357 & 2 & .131 & & 0 & 1 & .327 & $\begin{array}{l}.02 \\
6\end{array}$ \\
\hline & .055 & .787 & .005 & ${ }^{*} .045$ & .321 & .369 & .986 & & ${ }^{*} .011$ & $\begin{array}{l}.84 \\
3\end{array}$ \\
\hline \multirow{2}{*}{$\begin{array}{l}\text { Pronuncia } \\
\text { tion } \\
\text { fluency- } \\
\text { difficult }\end{array}$} & .107 & .081 & .142 & -.036 & .165 & -.103 & .325 & .327 & 1 & $\begin{array}{l}.11 \\
9\end{array}$ \\
\hline & .459 & .541 & .281 & .783 & .207 & .435 & ${ }^{*} .011$ & ${ }^{*} .011$ & & $\begin{array}{l}.36 \\
6\end{array}$ \\
\hline \multirow[t]{2}{*}{$\begin{array}{l}\text { Vocabular } \\
\text { y-Milta }\end{array}$} & -.641 & .795 & .678 & .235 & .431 & .107 & .142 & .026 & .119 & 1 \\
\hline & ${ }^{* * *} .0$ & $\begin{array}{l}0^{* * *} .00 \\
\end{array}$ & $\begin{array}{l}0^{* * \star} .00 \\
\end{array}$ & .071 & .001 & .414 & .281 & .843 & .366 & \\
\hline \multirow[t]{2}{*}{$\begin{array}{l}\text { Jewish } \\
\text { identity }\end{array}$} & .016 & .103 & .106 & .274 & -.081 & -.048 & .058 & -.012 & .058 & $\begin{array}{l}.11 \\
8\end{array}$ \\
\hline & .912 & .431 & .421 & ${ }^{*} .034$ & .541 & .717 & .659 & .927 & .663 & $\begin{array}{l}.37 \\
1\end{array}$ \\
\hline
\end{tabular}




\begin{tabular}{|c|c|c|c|c|c|c|c|c|}
\hline $\begin{array}{l}\text { Immi } \\
\text { grati } \\
\text { on } \\
\text { age }\end{array}$ & $\begin{array}{l}\text { Asse } \\
\text { ssors } \\
\text { overa } \\
\text { II } \\
\text { score }\end{array}$ & $\begin{array}{l}\text { Unvo } \\
\text { calize } \\
\text { d } \\
\text { word } \\
\text { s } \\
\text { score }\end{array}$ & $\begin{array}{l}\text { Readin } \\
\text { g } \\
\text { compre } \\
\text { hensio } \\
\text { n }\end{array}$ & $\begin{array}{l}\text { Pseudo } \\
- \\
\text { words } \\
\text { reading }\end{array}$ & $\begin{array}{l}\text { Pseudo- } \\
\text { words- } \\
\text { repetitio } \\
\text { n }\end{array}$ & $\begin{array}{l}\text { Phon } \\
\text { etic } \\
\text { delet } \\
\text { on }\end{array}$ & $\begin{array}{l}\text { Pronunci } \\
\text { ation } \\
\text { fluency } \\
\text {-easy }\end{array}$ & $\begin{array}{l}\text { Pronuncia } \\
\text { tion } \\
\text { fluency- } \\
\text { difficulty }\end{array}$ \\
\hline
\end{tabular}

acce

nt

\begin{tabular}{|c|c|c|c|c|c|c|c|c|c|c|}
\hline \multirow[t]{2}{*}{$\begin{array}{l}\text { Israeli } \\
\text { identity }\end{array}$} & -.532 & .394 & .419 & .312 & -.068 & .022 & -.148 & . 111 & -.177 & $\begin{array}{l}.47 \\
5\end{array}$ \\
\hline & ${ }_{00}^{* * *} .0$ & ${ }^{* *} .002$ & ${ }^{* *} .001$ & ${ }^{*} .015$ & .608 & .871 & .259 & .401 & .176 & 000 \\
\hline \multirow[t]{2}{*}{$\begin{array}{l}\text { Russian } \\
\text { identity }\end{array}$} & .264 & -.543 & -.445 & -.165 & -.377 & -.052 & -.136 & .111 & .003 & $\begin{array}{l}.53 \\
2\end{array}$ \\
\hline & .064 & $0^{* * *} .00$ & $0^{* * \star} .00$ & .206 & ${ }^{* *} .003$ & .693 & .299 & .397 & .979 & 000 \\
\hline \multirow[t]{2}{*}{$\begin{array}{l}\text { Conflict } \\
\text { ethos }\end{array}$} & -.054 & .171 & .192 & .221 & .054 & -.062 & -.042 & -.179 & -.041 & $\begin{array}{l}.30 \\
8\end{array}$ \\
\hline & .712 & .192 & .141 & .091 & .682 & .641 & .747 & .171 & .763 & $\begin{array}{l}{ }^{*} .0 \\
17\end{array}$ \\
\hline
\end{tabular}

A summary of the correlations presents all the links examined, indicating a positive correlation between immigration age and heaviness of accent, un-vocalized words score, difficult pronunciation fluency test, reading pseudo-words, and vocabulary. A correlation also exists between heaviness of accent and immigration age, un-vocalized words score, and vocabulary - as well as between vocabulary, immigration age, heaviness of accent, and Israeli identity.

In conclusion, this study sought to examine the links between accent, identity, language skills, and critical age. The Findings section presents various statistical tests designed to investigate the relations between the diverse parameters. The principal results indicate that a significant positive relation exists between critical age, language skills, and heaviness of accent. The findings also indicate that immigration prior to the age of twelve increases $L 2$ language ability and mitigates against developing an accent, with immigrants arriving after that age exhibiting a lower language-skill achievement level.

No difference was found in only one field, namely the difficult vocabulary test, with participants who had immigrated both prior and subsequent to the critical-age period finding it difficult to answer this test correctly. Similarly, while immigration age affects language, it does not affect the new identity the immigrant adopts. Likewise, accent does not reflect language ability.

An examination of the relation between accent and national identity revealed that identity, immigration age, and vocabulary level are linked. This language skill exhibited an association with Israeli identity and immigration age.

\section{Discussion}

This study set out to examine a number of links and relations between language, identity, accent, and the critical period, hypothesizing that relations would be found between all these variables. A review of the research literature reveals that a link exists between identity and language acquisition (Giles \& Byrne, 1982), between the critical period and language acquisition (Lenneberg, 1967), and between language skills and an immigrant's attitude towards his new home (Gardner, Margoret, \& Tremblay, 1999). We thus presumed that all the variables would probably be mutually related. In order to analyze the findings, we conducted various types of statistical tests in an attempt to establish the relations between them.

This hypothesis was confirmed, with early immigration age directly affecting L2 mastery levels. This finding corroborates the proposal that achieving language skills on a par with one's mother tongue after the age of twelve is a very difficult if not impossible task (Abu-Rabia \& Kehat, 2004). The ability to acquire another language and master it on a level very close to that of one's native tongue thus appears to be a natural and instinctive human attribute up until a certain age. While a young immigration age does not guarantee mother-tongue-level L2 mastery, immigration at a later age substantially increases the difficulty in doing so.

Although the critical-period theory has numerous proponents (Hakuta, 2003) it also has its detractors (Scovel, 2003). The debate focuses primarily on the question of its claim that age 12 constitutes the categorical cutoff point for 
acquiring L2 at a mother-tongue level (Singleton, 2003). The present study indicates the difficulty of accepting this theory without reservation, demonstrating that-across a number of fields-immigration before the age of twelve serves as a significant advantage. With respect to the corollary-that accent constitutes one of the parameters determined during the critical period (Komarova \& Nowak, 2001) - the current study suggests that language skills and accent are frequently two separate entities that do not interact with one another and that the ability to speak without an accent does not necessarily reflect a high verbal level (Flege et al., 2002).

Some scholars maintain that this circumstance derives from the fact that extensive exposure to language-even subsequent to the critical period-promotes the development of mother-tongue-level language skills (Piller, 2002). A situation may thus exist in which, while a person speaks with a heavy accent because he immigrated later than age twelve, he nonetheless achieves very high language skills in numerous areas because he is widely exposed to it in his daily life.

While no significant differences were found to exist between the various immigrant groups in a number of areasreading comprehension, repeating pseudo-words, and the difficult pronunciation fluency test-the abilities demonstrated by young and older immigrants are similar where both struggle rather than when one succeeds in matching the level of the other. A consistency exists in the gaps between the groups, with an inverse trend and relation identified between immigration age and verbal competence.

Early exposure to language appears to be reflected in a higher level of ability to acquire language skills (Flege \& Liu, 2002), with immigrants who made aliyah at a young age demonstrating greater ability in most fields than those who immigrated at an older age.

We hypothesized that language skills are related to accent level. This hypothesis was not confirmed, as accent and language skills did not appear to be byproducts of one another or interlinked. This finding can also explain the wellknown case of Joseph Conrad, who achieved very high language-skills levels but never lost his heavy Polish accent (Long, 1990).

It may be assumed that accent development and language-skills acquisition are not necessarily interrelated and may develop separately. Accent, associated with pronunciation (Komarova \& Nowak), is produced by listening and imitation-functions and skills that are at their prime at a young age (Shany \& Ben-Dror, 1997). Language skills may be constantly developed, on the other hand, through exposure to and repeated use of L2 (Piller, 2002) -although this circumstance does not extend to accent/pronunciation (Long, 1990).

In conjunction with the various theories, the current findings can point to an extensive working space with respect to everything related to language skills, which may be improved and enhanced to some degree-in contrast to accent, which is far less open to influence and dependent upon factors that cannot be abrogated once they have occurred (age and immigration). At the same time, numerous studies indicate that no one single brief period exists in which an accent inevitably develops, this rather depending on the degree of exposure to L2 and the frequency of its usage (Flege et al., 2006). Exposure alone, however, is not sufficient, and active practice-including attention to pronunciation-is also necessary (Munro \& Mann, 2005). This finding may be linked to the results of the present study, which suggests that the development of an accent is inversely related to immigration age. While this phenomenon may be explained in terms of length of exposure and degree of practice, it may also be claimed that constant exposure to one language makes it more difficult for the older immigrant to integrate additional phonological systems (Flege, 1999).

This being the case, the link between immigration age and heaviness of accent demonstrates that the older a child is when he immigrates the more likely he will be to have a heavy $L 2$ accent-a finding consistent with the criticalperiod theory.

While the significance of the critical period regarding the acquisition of language skills may be disputed (Piller, 2000), it is generally concurred that this is the period during which a child is likely not to develop an accent, where as such an achievement is virtually impossible later on due to the evolution and development of the mechanisms responsible for language acquisition (Komarova \& Nowak, 2001).

Here, we must ask whether immigration age affects other aspects of an immigrant's life. Can we make any inferences regarding how he will identity with his new country of residence, for example? Our findings indicate that immigration age does not serve as a predictor of the nature of the identity the immigrant will adopt, in keeping with the theory that identity is a dynamic entity based on a large number of interactions (Norton, 2000) which, occurring within an individual and between him and others, lead him to assume multiple identities.

Were identity determined and shaped at a single point in time, it would be reasonable to expect to find a link between immigration age and identity, with the latter comprised of sociological, psychological, and cultural elements (Goldberg \& Noels, 2006) that are functions of space and time. The dynamic nature of identity thus appears to enable an individual to continue to construct it as a function of time and space.

We hypothesized that identity and language skills do not exist in isolation but are linked to a sense of Israeli identity. Our findings demonstrate that, while immigration age affects heaviness of accent, it has no impact on the sense of Israeli identity.

It is frequently asserted that language serves as a tool for advertizing social identity (Lippi-Green, 1997) and that identity is forged on the basis of the interaction between various parts of the self (Kramsch, 2000). Our findings suggest that identity also heavily interacts with accent, the nature and heaviness of an accent often reflecting the immigrant's 
ethnic origin and thus affecting his sense of identity. Thus, for example, a person with a heavy Russian accent who also possesses conspicuous ethnic features will be identified by society as "Russian." On this basis, his identity-deriving from the interaction of various factors-will also be "Russian." It may also be surmised that adopting "Russian" identity will affect his willingness and motivation to speak and pronounce carefully and precisely (Flege, 1987) -this in turn influencing the heaviness of his accent.

Since language serves as one of the sources for the identity formation of members of a specific group (Miller, 2000), the link between language and identity found in the study is demonstrated as a link between accent and identityas accent more than any other indicator is immediately noticeable during spoken language production. Enabling identification of a person's origin, accent permits assumptions to be made about his origin, the country of his birth, and his background-thereby constituting a type of "calling card." Reciprocal relations may also exist between accent, society, and the individual, a person frequently unwittingly adopting the identity he seeks to present to the outside world via a specific form of pronunciation.

A sense of Israeli identity affects vocabulary level. While immigration age has a similar effect, the latter variable does not affect the nature of the identity a person adopts. This finding confirms the research hypothesis that a link exists between language skills, identity, and immigration age. Since there is a possible positive relation between language and social integration (Menahem \& Gajst, 2001), the latter may also affect a person's sense of identity, and it may be plausibly assumed that when an individual feels socially accepted he finds it easier to identify with society and feel himself to be "Israeli." This sense engenders a positive attitude towards language, with the immigrant who feels part of society finding it easier to express a willingness and true desire to assimilate into it (Eagly \& Chaiken, 1993) that is translated into greater use of the local language, and an increase of his mastery thereof.

It is also important to note that FSU immigrants tend to make aliyah for ideological reasons. While these motives might be expected to affect their motivation to acquire L2 skills, studies have demonstrated that this is not in fact the case (Abu-Rabia, 1999; Mesch, 2003). This gives greater weight to the above finding, indicating that although ideology per se is insufficient to provide the necessary motivation or ability to acquire L2, a sense of Israeli identity does affect verbal competence - in particular the breadth and quality of vocabulary.

The changes that have occurred since the beginning of the 1990s, during which Israeli society has become more varied and pluralistic (Cohen, 2001), may be assumed to have enabled immigrants to relax their grip on their Russian identity and develop an Israeli identity. This circumstance allows for the adoption of another identity and a greater desire to become familiar with the target culture and language, thereby broadening the immigrant's vocabulary.

In the past, Israeli society demanded that immigrants assimilate within it, thus creating a situation in which they tended to isolate themselves within closed groups and maintain their original identity. Today, however, its relatively openness gives olim the freedom to choose which identity they wish to adopt-this choice appearing to be made, to a large degree, on the basis of their attitude towards the target language.

Since identity and language are closely interrelated (Guiora, 1990), the level of a person's vocabulary indicates a primary language ability, as spoken language and thought are based above all on words. The nature and scope of one's vocabulary thus forms a crucial aspect of the ability to engage in an interaction and draw conclusions. This finding suggests that when an individual identifies with Israeli society he tends to make strenuous efforts to become part of the target culture. Language constitutes the gateway to such assimilation, as learning the target language demands that the immigrant increase his vocabulary in order to be able to communicate well with others. Our findings correspondingly demonstrate the existence of a positive link between the feeling of being an Israeli and the nature and scope of the immigrant's Hebrew vocabulary.

The finding indicating the effect of immigrant age on vocabulary indicates the significance of the critical period, with this language skill being the most affected by the critical-age period, with the exception of accent. The absence of interaction between the variables demonstrates the fact that two items can influence the acquisition of language without being influenced by each other. While the significance of early exposure to language is commonly recognized, immigration at a later date-when aliyah is informed by a sense of identity and identification with the target culture-may also function in the acquisition and expansion of language skills that are not dependent upon the critical period.

\section{Conclusions and Summary}

This study set out to examine the relations between language mastery, accent, the critical-age period, and Israeli identity. We administered a series of questionnaires and in-depth tests to a population of fifty FSU immigrants (students) who had made aliyah at various ages. This group was divided into two-those who had immigrated before they were twelve and those who had immigrated after that age. For purposes of comparison, we also included a control group, comprised of ten native-born Israelis whose mother tongue was Hebrew. All the groups filled out a questionnaire consisting of three parts that tested accent, language skills, and Israeli identity.

Analysis of the data demonstrated the existence of various links between the three central variables, as well as between their sub-variables. The findings indicated, first and foremost, that a positive relation exists between the age of exposure to language and the level of language skills-native-born Israelis exhibiting better language skills than either immigrant group; among the immigrants, those who had made aliyah prior to the age of twelve demonstrated higher language skills than those who had immigrated after the age of twelve in the majority of skills. 
At the same time, however, we found that vocabulary was the skill with respect to which the most unambiguous differences occurred, this field dividing the three populations most decisively and demonstrating significant divergences. A positive relation was found between the scope of vocabulary and identity: the more immigrants felt Israelis and identified with Israeli society and culture the broader their vocabulary.

We also found that while heaviness of accent did not affect verbal competence it did influence sense of identity. This is one of the key findings of this study - that heaviness of accent affects a person's sense of being an Israeli.

However, while this hypothesis was confirmed, that regarding the affect of heaviness of accent upon mastery of language skills was not. Although accent does not necessarily attest to verbal competence it both can and is likely to affect the sense of Russian-Israeli identity of an immigrant who makes aliyah and becomes an integral part of Israeli society and culture.

\section{References}

1. Aboud, F., \& Skerry, S. (1984). The development of ethnic attitudes: A critical review. Journal of Cross-Cultural Psychology, 15, 3-34.

2. Abu-Rabia, S. (1999). Attitudes and psycholinguistic aspects of first language maintenance among RussianJewish immigrants in Israel. Educational Psychology, 19, 133-148.

3. Abu-Rabia, S., \& Kehat, S. (2004). The critical period for second language pronunciation: Is there such a thing? Ten case studies of late starters who attained a native-like Hebrew accent. Educational Psychology, 1, 77-97.

4. Abu-Rabia, S., \& Siegel, L.S. (2003). Reading skills in three orthographies: The case of trilingual Arabic-HebrewEnglish-speaking Arab children. Reading and Writing, 16, 611-634.

5. Alba, R. (1999). Immigration and the American realities of assimilation and multiculturalism. Sociological Forum, 14, 3-25.

6. Al-Haj, M. (2002). Identity patterns among immigrants from the Former Soviet Union in Israel: Assimilation vs. ethnic formation. International Migration, 40, 49-70.

7. Aram, D. (1999). Mivh9an milta. In: Keitzad imahot mesayot lilyadeihim lehitmoded im misimot ktiva: nituah9 haqesher beyn ha-tivuh9 ha-imahi ve-ha-tifqud ha-oriyani shel ha-yeled be-qerev yeledei gan be-ir pituah9. PhD diss., Tel Aviv University (Hebrew).

8. Bailey, B. (2000). Language and negotiation of ethnic/racial identity among Dominican Americans. Language in Society, 29, 555-582.

9. Berry, J. (1990). Psychology of acculturation: Understanding individuals moving between cultures. In: R.W. Brislin (Ed.), Applied cross-cultural psychology (pp. 232-253). Thousand Oaks, CA: Sage.

10. Burrill, C. (1985). The sensitive period hypothesis: A review of literature regarding acquisition of a native-like pronunciation in a second language. Paper presented at a meeting of the TRI-TESOL Conference, Bellevue, WA, November 15.

11. Chiswick, B.R. (1986). Is the new immigration less skilled than the old? Journal of Labor Economics, 4, 168-192.

12. Chiswick, B.R. (2001). Soviet Jews in the United States: Language and labor. In: N. Lewin-Epstein, Y. Ro'i, \& P. Ritterband (Eds.), Russian Jews on three continents: Migration and resettlement (pp. 233-260). Oregon: Frank Cass.

13. Chiswick, B.R., \& Miller, W. (1995). The endogeneity between language and earnings: An international analysis. Journal of Labor Economics, 13, 246-288.

14. Chiswick, B.R., \& Miller, W. (1998). Language skills definitions: A study of legalized aliens. International Migration Review, 32, 877-900.

15. Clément, R. (1980). Ethnicity, contact and communicative competence in a second language. Toronto: Pergamon.

16. Cohen, D. (2001). Mediniut ha-aliyah ve-ha-qlita mi-shnot ha-70 ve-ad shnot ha-90 [Immigration and absorption policy from the 1970s to the 1990s]. Trends in Israeli Society, 1, 447-464 (Hebrew).

17. Cole, T., \& Leets, L. (1998). Linguistic masking devices and intergroup behavior: Further evidence of an intergroup linguistic bias. Journal of Language and Social Psychology, 17, 348-371.

18. Deutsch, A. (1997). Qri'at milot tefel [Reading pseudo-words]. Jerusalem: School of Education, Hebrew University (Hebrew).

19. Eagly, A.H., \& Chaiken, S. (1993). The psychology of attitudes. San Diego: Harcourt Brace Jovanovich.

20. Erickson, E.H. (1968). Identity: Youth and crisis. New York: Horton. 
21. Espenshade, T., \& Calhoun, C. (1993). An analysis of public opinion toward undocumented immigration. Population Research and Policy Review, 12, 189-224.

22. Fabbri, F., \& Dustmann, C. (2003). Language proficiency and labour market performance of immigrants in the UK. Economics Journal, 113, 695-717.

23. Fairclough, N. (1989). Language and power. London: Longman.

24. Fishman, J. (1972). Language and nationalism: Two integrative essays. Rowley, MA: Newbury House.

25. Fishman, J. (1986). Domains and the relationship between micro- and macrosociolinguistics. In: J. Gumperz (Ed.), Directions in sociolinguistics (pp. 435-453). Oxford: Blackwell.

26. Flege, J. (1987). A critical period for learning to pronounce foreign languages? Applied Linguistics, 8, $162-177$.

27. Flege, J. (1999). Age of learning and second language speech. In: D. Birdsong (Ed.), Second language acquisition and the Critical Period Hypothesis (pp. 101-131). Mahwah, NJ: Lawrence Erlbaum.

28. Flege, J., Birdsong, D., Bialystok, E., Mack, M., Sung, H., \& Tsukada, K. (2006). Degree of foreign accent in English sentences produced by Korean children and adults. Journal of Phonetics, 34, 153-175.

29. Flege, J., \& Liu, S. (2002). The effect of experience on adults' acquisition of a second language. Studies in Second Language Acquisition, 23, 527-552.

30. Flege, J., Yeni-Komshian, G., \& Liu, S. (1999). Age constraints on second-language acquisition. Journal of Memory and Language, 41, 78-104.

31. Gardner, R. (1979). Social psychological aspects of second language acquisition. In: H. Giles and R. St. Clair, Language and social psychology. Oxford/Baltimore: Blackwell/University Park Press.

32. Gardner, R. (1985). Social psychology and second language learning: The role of attitudes and motivation. London: Edward Arnold.

33. Gardner, R., Margoret, A.M., \& Tremblay, E.P. (1999). Home background characteristics and second language learning. Journal of Language and Social Psychology, 18, 419-437.

34. Garner, M. (1988). Ethnic languages in two small communities: Swedish and Russian in Melbourne. International Journal of the Sociology of Language, 72, 37-50.

35. Geva, E., Wade-Wooley, L., \& Shany, M. (1997). Development of reading efficiency in first and second language. Scientific Studies of Reading, 1, 119-144.

36. Giles, H. (1977). Language, ethnicity and intergroup relations. London: Academic Press.

37. Giles, H., Bourhis, R.Y., \& Taylor, D.M. (1977). Language, ethnicity and intergroup relations. In: Language, ethnicity and intergroup relations (pp. 23-33). New York: Academic Press.

38. Giles, H., \& Byrne, J.L. (1982). An intergroup approach to second language acquisition. Journal of Multilingualism and Multicultural Development, 3, 17-40.

39. Giles, H., \& Coupland, N. (1991). Language: Contexts and consequences. Buckingham: Open University Press.

40. Goldberg, E., \& Noels, K.A. (2006). Motivation, ethnic identity, and post-secondary education language choices of graduates of intensive French language programs. Canadian Modern Language Review, 62, 423-447.

41. Grosjean, F. (1997). Processing mixed language: Issues, findings, and models. In: A.M. De Groot and J.F. Kroll (Eds.), Tutorials in bilingualism: Psycholinguistic perspectives (pp. 225-253). Mahwah, NJ: Lawrence Erlbaum.

42. Guiora, Z. (1997). A psychological theory of second language pronunciation. Toegapaste Talwetenschap in Artikelen, 37, 15-23.

43. Guiora, Z., Beit-Hallahmi, B., Brannon, R., Dull, C., \& Scovel, T. The effects of experimentally induced changes in ego states on pronunciation ability in a second language: An exploratory study. Comprehensive Psychiatry, 13(5), 421-428.

44. Hakuta, K. (1986). The mirror of language: The debate on bilingualism. New York: Basic.

45. Hakuta, K., Bialystok, E., \& Wiley, E. (2003). Critical evidence: A test of the critical-period hypothesis for secondlanguage acquisition. Psychological Science, 14, 31-38.

46. Horenczyk, G. (2000). Conflicted identities: Acculturation attitudes and immigrants' construction of their social worlds. In: E. Olshtain and G. Horenczyk (Eds.), Language, identity and immigration (pp. 13-31). Jerusalem: Magnes.

47. Komarova, N.L., \& Nowak, M.A. (2001). Natural selection of the critical period for language acquisition. Biological Sciences, 268, 1189-1196. 
48. Kramsch, C. (2000). Second language acquisition, applied linguistics, and the teaching of foreign languages. Modern Language Journal, 84, 311-326.

49. Kramsch, C. (2001). Literacy, equity, accesses for the immigrant learner. In: E. Olshtain and G. Horenczyk (Eds.), Language, identity and immigration (pp. 325-338). Jerusalem: Magnes.

50. Lambert, W.E. (1975). Culture and language as factors in learning and education. Paper presented at the Fifth Annual Learning Symposium on "Cultural Factors in Learning." Western Washington State College, Bellingham.

51. Lee, J.S. (2002). The Korean language in America: The role of cultural identity in heritage language learning. Language, Culture and Curriculum, 15, 118-133.

52. Lenneberg, E. (1967). Biological foundations of language. New York: Wiley \& Sons.

53. Liang, X. (2006). Identity and language functions: High school Chinese immigrant students' code-switching dilemmas in ESL classes. Journal of Language, Identity \& Education, 5, 143-167.

54. Lippi-Green, R.L. (1997). English with an accent: Language, ideology, and discrimination in the United States. London/New York: Routledge.

55. Long, M.H. (1990). Maturational constraints on language development. Studies in Second Language Acquisition, $12,251-285$

56. Marx, N. (2006). Never quite a "native speaker": Accent and identity in the L2—and the L1. Canadian Modern Language Review, 59, 274-281.

57. Menahem, G., \& Gajst, I. (2001). Language and occupation among Soviet immigrants. In: E. Olshtain and G. Horenczyk (Eds.), Language, identity and immigration (pp. 301-325). Jerusalem: Magnes.

58. Mesch, G. (2003). Language proficiency among new immigrants: The role of human capital and social conditions-The case of immigrants from the FSU in Israel. Sociological Perspective, 46, 41-58.

59. Miller, J.M. (2000). Language use, identity, and social interaction: Migrant students in Australia. Research on Language and Social Interaction, 33, 69-100.

60. Munro, M., \& Mann, V. (2005). Age of immersion as a predictor of foreign accent. Applied Psycholinguistics, 26, 311-341.

61. Norton, B. (2000). Identity and language learning: Gender, ethnicity and educational change. New York: Longman.

62. Olshtain, E., \& Kotik, B. (2000). The development of bilingualism in an immigrant community. In: E. Olshtain and G. Horenczyk (Eds.), Language, identity and immigration (pp. 201-219). Jerusalem: Magnes.

63. Phinney, J.S. (1990). Ethnic identity in adolescents and adults: Review of research. Psychological Bulletin, 108, 499-514.

64. Phinney, J.S. (1992). The multigroup ethnic identity measure. Journal of Adolescent Research, 7, 156-176.

65. Phinney, J.S., Romero, I., Nava, M., \& Huang, D. (2001). The role of language, parents, and peers in ethnic identity among adolescents in immigrant families. Journal of Youth and Adolescence, 30, 135-151.

66. Piller, I. (2002). Passing for a native speaker: Identity and success in second language learning. Journal of Sociolinguistics, 6, 179-206.

67. Remennick, L. (2003). Language acquisition as the main vehicle of social integration: Russian immigrants of the 90s in Israel. International Journal of the Sociology of Language, 164, 83-105.

68. Remennick, L. (2004). Language acquisition, ethnicity and social integration among former Soviet Union immigrants of the 1990s. Ethnic and Racial Studies, 27, 431-454.

69. Sachdev, I., \& Bourhis, R.Y. (1984). Minimal majorities and minorities. European Journal of Social Psychology, $14,35-51$.

70. Schumann, J.H. (1978). The acculturation model for second language acquisition. In: R.C. Gringras (Ed.), Second language acquisition and foreign language teaching (pp. 27-50). Washington, DC: Center for Applied Linguistics.

71. Scovel, T. (1988). A time to speak: A psycholinguistic inquiry into the critical period for human speech. Boston: Newbury House.

72. Scovel, T. (2003). A critical review of the critical period research. Annual Review of Applied Linguistics, 20, 213223.

73. Shany, M., \& Ben-Dror, A. (1997a). Mivh9an qri'at milim lo menuqadot [Reading unvocalized words]. In: Mivh9anei halutz (Hebrew). 
74. Shany, M., \& Ben-Dror, A. (1997b). Mivh9an muda'ut fonologit [Phonological awareness test]. University Clinic for Learning Disabilities, University of Haifa (Hebrew).

75. Shatil, A. (1997). H9azara al milot tefel [Repetition of pseudo-words]. University Clinic for Learning Disabilities, University of Haifa (Hebrew).

76. Singleton, D. (2003). Age and second language acquisition. Annual Review of Applied Linguistics, 21, 77-89.

77. Tajfel, H., and Turner, J.C. (1979). An integrative theory of intergroup conflict: The social psychology and intergroup relations. Monterey, CA: Brooks/Cole.

78. Teitelman, L. (2006). Qsharim beyn gibush zehut Yisraelit le-vein metrimim la-tarbut be-h9evra ha-Yisraelit. Hashva'a bein no'ar olim ve-no'ar na'ale mi-h9ever ha-amim [Links between the consolidation of Israeli identity and measures of Israeli society: A comparison between immigrant youth and FSU immigrant youth.] MA thesis, Tel Aviv University (Hebrew) 